\title{
Teacher Residency as Alternative Pathway to Licensure
}

\author{
Bryan S. Zugelder (Corresponding author)
}

Department of Learning, Technology and Leadership Education, James Madison University

395 S. High Street, Harrisonburg, Virginia 22801, United States

Tel: 1-540-568-6572Ｅ-mail: zugeldbs@jmu.edu

\begin{abstract}
Mark L'Esperance
Office of the Dean-College of Education, James Madison University

395 S. High Street, Harrisonburg, Virginia 22801, United States

Tel: 1-540-568-6572Ｅ-mail: lesperme@jmu.edu
\end{abstract}

Patricia J. Anderson

Department of Elementary Education and Middle Grades Education, East Carolina University College of Education-Speight Building, Greenville, North Carolina 27858, United States Tel: 1-540-568-6572_E-mail: andersonp@ecu.edu

Paige Everett

Department of Elementary Education and Middle Grades Education, East Carolina University College of Education-Speight Building, Greenville, North Carolina 27858, United States Tel: 1-540-568-6572Ｅ-mail: everettp@ecu.edu

\section{Lesli Grandy}

Department of Elementary Education and Middle Grades Education, East Carolina University College of Education-Speight Building, Greenville, North Carolina 27858, United States Tel: 1-540-568-6572_E-mail: grandyl@ecu.edu 


\begin{abstract}
Teacher residencies have been an ongoing discussion in the educator preparation world for nearly a decade. This paper describes a promising practice in program design at a university that offers alternative pathways to licensure to meet the demands of school districts, especially in economically disadvantaged communities in one region of the United States. The one-year residency model was developed to address the teacher shortage in a state with growing teacher attrition. Aligned with recent legislation that created a residency license, a traditional educator preparation program examined its strengths and incorporated the most critical needs for novice teacher success to offer a one-year teacher residency as an alternative pathway. The residency model was co-constructed with school district personnel and teacher education faculty to focus on the most critical dimensions of teaching that include planning, instruction, and assessment. After one year, the feedback from school district personnel included high favor for readiness to teach. Residency candidates reported increased self-efficacy. The residency program has implications for future research and potential replication at other institutions of higher education.
\end{abstract}

Keywords: Teacher turnover, Alternative licensure, Teacher retention, Clinical teaching practice, Teacher residency

\title{
1. Introduction
}

\subsection{Teacher Turnover Dilemma}

Unlike most other professions, teacher turnover rates in the United States are more prevalent in education, especially among those who teach in schools with the highest needs (Ingersoll \& Merrill, 2010; Sutcher et al., 2016). It is also a common national trend that the teaching force has a significantly large number of teachers with five years of experience or less (Barth, et al., 2016). In response to the teacher shortage and greening of the profession, many states have enacted policy that allows for school districts to hire inexperienced college graduates from a broad range of fields. In turn, non-traditional routes to licensure have become more prevalent and popular in the state. This practice has been encouraged by national policy groups that recommend states should be flexible to the needs of non-traditional teacher candidates in a growing effort to staff classrooms, especially in historically disadvantaged communities (National Council on Teacher Quality, 2018). As of 2018, only 25 states allowed for flexibility in hiring non-traditional teacher candidates, accounting for only $50 \%$ of the country (Whitford et al., 2018).

\subsection{Sustaining the Teacher Workforce}

Teacher education programs in the United States are often scrutinized by organizations that support multiple pathways, such as the National Council on Teacher Quality (2018). 
Additionally, university-based teacher education programs are criticized by policy makers for lacking relevance and recency in preparing teachers for the demands of the profession (Guha, et al., 2017). Consequently, states have extended invitations to alternative licensure competitors to prepare teachers faster and cheaper than traditional teacher education programs housed at universities (Whitford et al., 2018).

Universities have long strategized recruitment efforts to attract potential candidates for admission into programs, providing a pipeline for their district partners. The ongoing challenge, however, is sustaining the teacher workforce for the benefit of students (Ronfeldt, et al., 2013). Teacher longevity continues to be problematic in critical content areas and hard-to-staff school communities with ongoing teacher turnover, and traditional teacher preparation programs struggle to supply the demand for teachers, especially in challenging environments that include rural and urban settings (Barth et al., 2016; Sutcher et al., 2016). Teacher preparation programs have embraced stronger clinical practice and experiential learning by co-constructing with district partners learning for teacher candidates in diverse settings, as a strategy to help candidates face the reality of the classroom (NCATE, 2010).

\subsection{Promising Solution}

This article describes a teacher residency program developed by a traditional university educator preparation program. While enrollment in traditional preparation routes at the targeted institution has continued to increase, the demand for teachers grows exponentially beyond the number produced through traditional routes. The program described is a post-baccalaureate teacher residency in elementary education designed to meet the needs of alternative licensure. Program development has encouraged thinking beyond the traditional scope of teacher education to meet the demands of changing workforce needs.

\subsection{Educator Preparation}

Teacher education scholars recognize the importance of theory in content and methods courses and also emphasize frequent and meaningful practice in real-world settings, allowing candidates to develop the craft of teaching (Batchelor, 2012; Guha \& Darling-Hammond, 2017; Thorpe, 2014). For nearly a decade, teacher education programs have been charged with rethinking the ways that teacher candidates are prepared by centering coursework around clinical practice (Chen et al., 2017; NCATE, 2010), leading to potential for stronger partnerships between schools and universities. The Council for Accreditation of Educator Preparation (CAEP, 2020) recommends that effective partnerships demonstrate evidence of co-construction of teaching and learning between schools and universities, where candidates are embedded in experiences that resemble more clinical models of practice (Davies et al., 2015). Residency experiences provide candidates with practice in one setting for longer periods of time and with deeper connections with a clinical educator (Dee, 2012; Guha \& Darling-Hammond, 2017).

Burn and Mutton (2015) completed a comprehensive review of research surrounding clinical practice, where pre-service teachers apply knowledge in skills in supervised school settings, and made four major claims: (a) clinical experience positively benefits novice teacher 
learning, integrating theory and practice, which leads to greater self-efficacy; (b) there is a positive relationship between clinical preparation and teacher effectiveness; (c) completers of programs that include emphasis on greater quality clinical practice increase teacher perception of preparedness; and (d) extended clinical experiences with integrated university coursework positively impacts long-term teacher retention, effectiveness, and efficacy. These findings from the meta-analysis have implications for educator preparation programs and the design of clinical practice.

With $50 \%$ of the nation's states participating in alternative routes for teacher preparation (Whitford et al., 2018), traditional methods of training novice teachers may not be the only solution. Traditional programs can strategize ways to diversify their approach in a diverse market of those interested in pursuing teaching careers. Sass (2015) found in a longitudinal study of archival categorical data that alternative licensure teachers possess stronger content knowledge than their peers who were prepared from a traditional pathway. Conversely, teachers prepared by the traditional pre-service university-based programs tend to be stronger in pedagogical methods than their alternative licensure counterparts (Bastian \& Marks, 2017; Pritchard, 2017).

The varied retention rates and effectiveness of teachers prepared via alternative routes are reported in the research (Henry et al., 2014; Sass, 2015; Whitford, et al., 2018; Zhang \& Zeller, 2016). Nonetheless, traditional teacher education programs continue to yield criticism across the country, especially in political debate. Colleges of education are often criticized for organizing coursework around what professors want to teach, rather than what students need to learn (Hargreaves \& Fullan, 2012). Further, teacher education faculty members' engagement in design or redesign of programs is critical for gaining their commitment to preparing teachers ready for classroom challenges (McDiarmid, 2019). As accountability standards in the P-12 arena continue to rise, teacher education programs have become more regulated, changing the landscape of university-based teacher training (Bohan, 2016).

\subsection{Teacher Residencies}

The National Center for Teacher Residencies (NCTR-2020) described teacher residents as practicing novice teachers who work alongside an effective mentor as they also learn pedagogy. While teacher residencies build upon the components of typical clinical experiences, such as teacher internships, they are designed to mirror the medical model of training, where there is intense content built into and around supervised practice (Dennis, 2016; NCTR, 2020). Washburn-Moses (2017) declared that teacher residencies are the next generation in educator preparation. Dennis (2016) outlined major factors of teacher residencies that lead to high quality, including the purpose of clinical experiences, redesigned coursework and program entry, and university-school partnerships that yield enhanced collaboration. Teacher residencies also affirm that learning to teach is developmental and does not stop, providing a teacher candidate with immersed experiences in the classroom with coinciding pedagogical training (Goodwin et al., 2018).

Pike and Carli (2020) recommended that educator preparation programs employ teacher residencies as a strategy to enhance clinical experiences for candidates. Garcia and Garza 
(2019) showcased how a teacher residency program can strengthen the teacher pipeline, because of the various components of support that include cohort-based education, intentional mentoring from an effective educator, and bridge of theory to practice. The connection between theory and practice, with practice as the center of learning, is the essence of an effective teacher residency model Dennis (2016). Teacher residencies vary in terms of organization and support; however, the link between coursework and field work is critical to success (Washburn-Moses, 2017). Teacher residencies have pushed beyond the boundaries of educator preparation, because of the increased focus on practice has called for non-traditional delivery of teacher education, with more emphasis on in-field practice and less weight on classroom-based theory (Dennis, 2016; Goodwin et al., 2018).

\subsection{Non-traditional Education}

In a study of college-level faculty who worked with nontraditional students, the faculty held very positive beliefs about their students; however, they did very little to make accommodations for them, manifesting the public criticism of traditional university education (Brinthaupt \& Eady, 2014). Kurts et al. (2007) identified the removal of typical college obstacles as an important strategy for working with non-traditional teacher education candidates who pursued alternative licensure, including sensitivity to their life schedules and design around what is relevant to their professional context. Non-traditional adult learners benefit more from experiential learning, where they apply theory in practice (Kenner \& Weinerman, 2019).

\section{Context}

Across the United States, working conditions continue to pose challenges in the recruitment and retention of high-quality teachers, especially in historically disadvantaged communities that mostly employ the least experienced teachers (Barth et al., 2016). While teacher preparation programs have seen a steady increase in enrollment, the demand for teachers, specifically in low-wealth schools, continues to rise (University of North Carolina System, 2020). In a state that eliminated teachers earning financial compensation for completing a master's degree, there is more of a need for quick pathways to licensure to keep up with the number of vacancies and attrition.

\subsection{The Teacher Workforce}

The setting for this program is in North Carolina, where more than 10,000 teachers have retired since 2010 (North Carolina Department of Public Instruction, 2018). These data continue to show the pressing need for teacher recruitment, especially in schools with already high teacher turnover. The number of highly-skilled, prepared, and competent teachers continues to decrease, leaving students in underserved areas with less access to the quality education they deserve. State-level school performance data continue to show that schools with the highest percentage of turnover and the highest levels of poverty tend to have the teachers with the least amount of experience (North Carolina Department of Public Instruction, 2020a). In historically distressed communities, this has posed a dilemma in preparing P-12 students to be college and career ready. 
In 2017, the state's General Assembly passed Senate Bill 599 (North Carolina General Assembly, 2017) to expand providers of educator preparation programs and to change the landscape for licensure pathways. This was an attempt to provide additional access for school districts to hire teachers without compromising quality preparation. Senate Bill 599 created a new category of licensure named as the residency license. The licensure pathway requires that educator preparation programs require training and field experiences prior to entering the classroom. This article uses clinical practice and field experiences interchangeably. Components of the bill include the following:

- $\quad$ residency license is a one-year license, renewable twice, designed to meet alternative licensure;

- $\quad$ residency lasts for a minimum of one year;

- $\quad$ candidate must possess a bachelor's degree;

- $\quad$ ongoing support must be provided to the candidate throughout the entire residency.

The bill also stated that educator preparation programs do not have to be housed at institutions of higher education; therefore, any provider, public, for-profit, or out-of-state, could offer a pathway to licensure. The state's department of education further defined the residency license with criteria for issuance (North Carolina Department of Public Instruction, 2020b):

- $\quad$ earned bachelor's degree;

- $\quad$ earned 2.7 GPA on the degree;

- completion of 24 semester hours of coursework in the licensure area or passed a content area examination;

- $\quad$ enrolled in a recognized educator preparation program;

- $\quad$ offered employment by a Local Education Agency.

Regardless of pathway, all providers must ensure the same criteria to maintain state program approval for licensure of its completers. Whether public, for-profit, or out-of-state, all providers must submit plans and outcome data to receive approval from the state to award educator licenses.

\subsection{The Targeted Institution}

The residency program described in this paper was developed at one higher education institution that partners with nearly $40 \%$ of school districts in the state. College-wide enrollment is near 29,000 students, $20 \%$ of whom are in graduate programs. The university is classified as a Carnegie-designated higher research activity institution (Indiana University School of Education, 2017). While it resides in a metropolitan area of more than 150,000 people, the institution serves mostly rural areas of the state. The university is the largest producer of teachers in the state's public higher education system (United States Department of Education, 2017). The College of Education employs nearly 200 faculty and staff, serving 
more than 3,000 students annually.

The targeted institution offers undergraduate and graduate level degrees in education that include elementary, early childhood, middle grades, and secondary education. Students may also complete licensure-only programs, which are non-degree seeking. While the targeted institution remains the largest producer of traditionally-prepared teachers in the state, its 42 partnership school districts continue to struggle with staffing the ongoing vacancies due to factors that influence rural settings. These include teacher pay, remote geographical areas, limited resources, and lack of support. Teacher turnover is higher in this region of the state; therefore, the targeted institution is committed to helping the partnership districts meet the demand for teachers by offering the residency program as an alternative route for teachers seeking licensure.

\subsection{Departmental Action}

The faculty in the Department of Elementary Education and Middle Grades Education (ELMID) took the lead for the college to develop a residency program that would align with its traditional preparation pathway. The described residency is a post-baccalaureate program in elementary education, which continues to surface as a shortage area in the targeted region of the state. Completers of residency do not earn a degree; however, they fulfill the requirements of licensure. The faculty met with school district representatives to co-construct courses that included high-leverage skills teachers need to be successful, in the areas of planning, instruction, and assessment, all critical dimensions of edTPA (Pearson, n.d.; Stanford Center for Assessment, Learning, and Equity-SCALE, 2017). The purpose for edTPA as a required component is because of a comprehensive, statewide study that determined predictive validity of candidate performance on edTPA and teacher effectiveness during the first years of teaching (Bastian et al., 2018). This predictive validity study drove policy in North Carolina that fulfilled the expectations for candidates to demonstrate impact on student learning in the settings where they complete their clinical experiences.

edTPA is a teacher performance assessment, developed by Stanford University, used to assess a teacher candidate's strengths in planning, instruction, and assessment (SCALE, 2016). The critical dimensions of teaching include rubric constructs that assess candidate performance in planning, instruction, and assessment. The constructs provide a frame by which teacher candidates demonstrate evidence along a continuum of proficiency. The constructs, while separated by domain, are meant to be intertwined in practice.

As part of the edTPA portfolio submitted by a candidate, he or she provides applicable evidence for an external, nationally-trained evaluator to review, and includes reflective commentary to triangulate the critical dimension of teaching. Therefore, a teacher candidate may demonstrate knowledge of students in the planning domain, but may also connect that with practices in instruction and assessment. Results from edTPA can be used as a mentoring tool to guide candidates in identifying strengths and areas for improvement based on aligned rubrics, which can carry on into practice after several years of program completion.

edTPA requires a candidate to submit video evidence, lesson plans, student work, reflective 
commentary, which is all scored by trained national experts. Successful completion of edTPA is a required component of the traditional teacher preparation pathway at the targeted institution and also included as a completion requirement for the residency program. Table 1 showcases the specific rubric constructs aligned with planning, instruction, and assessment.

Table 1. Critical dimensions of teaching and rubric constructs

\begin{tabular}{|l|l|}
\hline Dimension & Rubric Constructs Assessed \\
\hline Planning & $\begin{array}{l}\text { Planning for content understanding } \\
\text { Planning for varied student learning needs } \\
\text { Knowledge of students } \\
\text { Identifying and supporting language demands } \\
\text { Planning assessments }\end{array}$ \\
\hline Instruction & $\begin{array}{l}\text { Learning environment } \\
\text { Engaging students in learning } \\
\text { Deepening student learning } \\
\text { Subject-specific pedagogy } \\
\text { Analyzing teaching effectiveness }\end{array}$ \\
\hline Assessment & $\begin{array}{l}\text { Analysis of student learning } \\
\text { Providing feedback to students } \\
\text { Student use of feedback } \\
\text { Assessing students' language use } \\
\text { Using assessment to inform instruction }\end{array}$ \\
\hline
\end{tabular}

\section{The Residency Program}

The ELMID department subscribes to the idea that effective teachers must be able to successfully perform a multitude of teacher performance indicators rather than just knowing about content and minimal teaching skills and dispositions (Darling-Hammond \& Oakes, 2019). Although traditional educator preparation programs are challenged to look at the number of required credit hours, alternative pathways are even more condensed. Therefore, developing the residency program pushed the department to examine how it could maximize what teachers needed for immediate application in practice. This would result in a condensed offering of courses that focused solely on the highest leverage skills teachers need in planning, instruction, and assessment, while providing the structure for them to augment their already-demonstrated content knowledge with strong pedagogical training. Individualized coaching and mentoring by the residency instructors supplement the need to address the contextual considerations of each candidate's unique setting. 
An ad hoc, volunteer faculty group in the ELMID department were identified by the Department Chair to work on developing the residency curriculum. To begin, it was necessary to identify the pedagogical content required to meet licensure and to provide depth in the understanding and application of planning, instruction, and assessment. In a traditional program, candidates would enroll in methods courses aligned with applicable content areas; however, the residency program, due to the time constraints required by Senate Bill 599, created a stipulation and limit in the number of courses that could be offered. Candidates admitted into the residency program still must meet the content required by the Senate Bill, including 24 hours of content or passing the content area licensure exam, to demonstrate knowledge of the content in the teaching area.

\subsection{Course Exploration}

Through the college leadership team and department leadership, it was determined that new courses were needed to explicitly address the unique needs of residency. While existing courses in the ELMID department addressed planning, instruction, and assessment, they were ultimately designed for students in the traditional pathway. Creating new courses for the residency program not only ensured specific focus on the critical dimensions of teaching needed for residency candidates, but also would create a platform for cohorts of teachers and the alignment of faculty who would develop and facilitate the delivery of the residency. Various strategies were brainstormed to determine if courses would follow the traditional university calendar. There was some thought given to a modified schedule, such as shorter semesters; however, the ELMID department's first effort was to align the residency program within the traditional semesters to allow time for appropriate teacher development.

In reviewing Senate Bill 599 and the needs for beginning teachers, the ELMID department agreed that, in order to accomplish the residency model in a one-year time frame, five courses were needed. This would allow for non-traditional students, who would be working as full-time teachers, to undertake the coursework needed and would provide a schedule that would match the needs of teachers in the partnership school districts. Four courses would be developed and overseen by the ELMID department. Two additional pedagogical courses would be developed and provided by the college's other departments to ensure that residency teachers learned how to work with students with disabilities and received appropriate instruction in foundations of literacy. The four ELMID courses that addressed planning, instruction, and assessment were named:

1. TCHR 4001, Curriculum, Instruction, and Assessment

2. TCHR 4003, Classroom Management and Child/Adolescent Development

3. TCHR 4491, Residency I

4. TCHR 4992, Residency II 


\subsection{Alignment of Course Objectives}

Faculty members worked to identify existing courses in the traditional program that addressed the critical dimensions of planning, instruction, and assessment, and determined where holes might need to be filled. A list of existing course objectives mapped what existed and to determine where new objectives were needed based on overarching purpose and desired content.

TCHR 4001 includes how to design lesson plans using the format commonly used throughout North Carolina. The lesson plan is the basis for how teachers are expected to develop and deliver lessons aligned with backward design (Wiggins \& McTighe, 2012); this process ensures a thorough mapping of how a candidate will elicit higher-order thinking, effective questioning, and designing assessments aligned with the goal of the lesson. Table 2 shows the alignment of existing objectives and where one new objective was needed to ensure that the content and purpose of the residency were addressed for curriculum and standards, but also in the area of assessment.

Table 2. TCHR 4001 objectives

\begin{tabular}{|l|l|}
\hline Objective & Originating Course \\
\hline $\begin{array}{l}\text { To understand, analyze, assess, and evaluate teaching-learning } \\
\text { process through reflection }\end{array}$ & Introduction to Education \\
\hline $\begin{array}{l}\text { Categorize, analyze, and interpret the major goals and objectives of } \\
\text { the state standards }\end{array}$ & Curriculum \& Standards \\
\hline $\begin{array}{l}\text { Identify, explain, and critique different types of state, district, and } \\
\text { classroom assessments and they inform/drive instructional practice }\end{array}$ & Curriculum \& Standards \\
\hline $\begin{array}{l}\text { Design, plan, and evaluate lesson plans based on goals and } \\
\text { objectives in state standards using the 6-step process }\end{array}$ & Learning Theory/Instruction \\
\hline $\begin{array}{l}\text { Create curriculum content, instructional activities, and evaluation } \\
\text { strategies based on developmental appropriateness, differentiating } \\
\text { to accommodate diverse individual, family, and sociocultural needs }\end{array}$ & Learning Theory/Instruction \\
\hline $\begin{array}{l}\text { Use appropriate technology in planning and implementing } \\
\text { instruction }\end{array}$ & Learning Theory/Instruction \\
\hline Analyze examples of student work and sets of student data & New Objective \\
\hline
\end{tabular}

TCHR 4003 includes classroom management, intertwined with child and adolescent development, where theories are learned and applied in practice. Table 3 shows the alignment of existing objectives and the originating course where those objectives are housed needed to create TCHR 4003. No new objectives were needed, since existing courses fulfilled the 
desired outcomes for classroom management as well as child and adolescent development.

Table 3. TCHR 4003 objectives

\begin{tabular}{|l|l|}
\hline Objective & Originating Course \\
\hline $\begin{array}{l}\text { Understand the nature of elementary children and their } \\
\text { relationship with the teacher, instructional program, and school } \\
\text { environment }\end{array}$ & Introduction to Education \\
\hline $\begin{array}{l}\text { Apply and utilize theories and principles of learning, } \\
\text { development and motivation and analyze their implications for } \\
\text { the planning of individual lessons/activities }\end{array}$ & Learning Theory/Instruction \\
\hline Apply knowledge of classroom management theories/techniques & Classroom Management \\
\hline $\begin{array}{l}\text { Synthesize classroom management and instructional skills into } \\
\text { strategies that can be used in classroom situations }\end{array}$ & Classroom Management \\
\hline
\end{tabular}

TCHR 4991 is the Residency I course, the first in the sequence of field work, where the candidate plans and delivers lessons to address the unique learning needs of his or her classroom. TCHR 4992 is the Residency II course. During Residency II, candidates demonstrate a culminating, summative experience of the program. Tables 4 and 5 show the alignment of existing objectives and the need for new objectives to meet the purpose and content of TCHR 4991 and TCHR 4992. For TCHR 4992, all new objectives were needed to fulfill the desired outcomes for the Residency II course.

Table 4. TCHR 4991 objectives

\begin{tabular}{|l|l|}
\hline Objective & Originating Course \\
\hline $\begin{array}{l}\text { Understand the roles of the teacher, including those of } \\
\text { decision-maker and reflective thinker }\end{array}$ & Introduction to Education \\
\hline $\begin{array}{l}\text { Understand the various components and requirements of the } \\
\text { program at the university }\end{array}$ & Introduction to Education \\
\hline $\begin{array}{l}\text { Research and identify effective strategies that can be used to reach } \\
\text { diverse students and their families based on individual classroom } \\
\text { context }\end{array}$ & Classroom Management \\
\hline $\begin{array}{l}\text { Implement lesson plans based on goals and objectives in the state } \\
\text { standards using the 6-step lesson plan process }\end{array}$ & Learning Theory/Instruction \\
\hline $\begin{array}{l}\text { Identify assessments within a lesson plan and evaluate their } \\
\text { effectiveness }\end{array}$ & New Objective \\
\hline
\end{tabular}


Table 5. TCHR 4992 objectives

\begin{tabular}{|l|l|}
\hline Objective & Originating Course \\
\hline Use assessment data to differentiate instruction & New Objective \\
\hline Modify lessons using assessment data & New Objective \\
\hline Understand program completion and licensure requirements & New Objective \\
\hline $\begin{array}{l}\text { Design, plan and evaluate lessons based on goals and objectives in } \\
\text { the state standards, using the 6-step process and peer review }\end{array}$ & New Objective \\
\hline
\end{tabular}

At the conclusion of the formulation of the course objectives mapping, the ELMID faculty voted to approve the courses as aligned with existing and newly-created objectives. A team of six faculty within the department, as well as a school district representative, volunteered to work collaboratively to design the new courses. The task pushed the faculty to think beyond the traditional scope of instructional design and delivery. It was necessary to use the mapped course objectives to determine how residency candidates would be assessed in a realistic manner, while not compromising quality.

\section{Program Design}

While legislation mandated what residency programs should include, the ELMID faculty was determined to ensure that quality and rigor superseded compliance. While every teaching concept was viewed important, the faculty were committed to focusing on practices that were applicable immediately. Since residency was centered around practice, individualized coaching and mentoring around strategies were necessary to provide real-time instruction based on each candidate's unique classroom and school context.

Rather than having one member of the faculty group simply charged with the responsibility of creating a course, the seven-member workgroup operated as a think tank to make decisions about the scope and sequence of the program. In the traditional program, teacher education candidates learn backward design, a concept in planning that starts with the end in mind, focused on desired outcomes or objectives that would be met as a result of the planning to get there (Wiggins \& McTighe, 2012). Given that the course objectives showed alignment with existing courses, the workgroup dove deep into the content of the courses where the objectives resided. It made practical sense at first to align existing modules with course objectives. Staying true to the backward design concept, however, was not that easy. In the spirit of backward design, the program described here is presented in reverse sequence, with the ultimate goal of successful candidate completion and readiness to teach on without clinical supervision upon finishing the program.

The courses were designed to be offered completely online using the university's learning management system. Courses were structured asynchronously and synchronously to provide self-pacing and opportunities for interaction with the instructors and peers. The courses were offered during the traditional university semesters, including fall and spring, which were 15 
weeks long, and two summer sessions, which were each five weeks. The residency program was delivered completely online through the university's learning management system. Modules were created by the workgroup to ensure that every course followed the same feel, look, and structure. This was to address the non-traditional student's need to feel successful in an online environment.

\subsection{TCHR 4992, Residency II}

Residency II is the culminating course, where candidates complete a summative assessment in planning, instruction, and assessment. In order to satisfy completion for Residency II, candidates are required to successfully complete edTPA. Therefore, the candidates must be able to plan and deliver lessons, submit the delivery of the lessons via video, and reflect upon the feedback provided by their Residency II instructor. Feedback provided on lessons includes all points of the 6-step process (e.g., Table 2). The Residency II instructor provides feedback on lessons with indicators that include student engagement, deepening student thinking, student and teacher use of assessment, and supports provided for building academic language. This practice mirrors what is required for edTPA, where candidates plan and deliver three lesson segments and write commentary that addresses their decision-making and reflective skills in planning, instruction, and assessment.

TCHR 4992 is a heavily-scaffolded course where the candidate applies all of the pedagogical knowledge learned throughout the residency in the applicable setting. While each course is centered around his or her classroom context, TCHR 4992 provides the opportunity for the candidate to put everything together in a complex manner to address all components of planning, instruction, and assessment. A key assessment in this course is a peer review of the video lesson, where candidates watch each other's videos and provide feedback based on the indicators addressed by the Residency II instructor. This assessment not only helps triangulate the feedback provided by the instructor, but it helps to enhance the candidate's understanding of the critical dimensions.

\subsection{TCHR 4991, Residency I}

Residency I was designed as the initial field experience, where candidates apply initial understanding of lesson plan development and delivery, submit video-recorded lessons, and reflect upon feedback provided by their residency instructor. During Residency I, candidates must also apply depth of understanding in the state standards, backward design, and developing a lesson plan (e.g., Table 2 outlines components of the lesson plan). Major emphasis on the development of the plan is focused on the edTPA rubrics aligned with knowledge of students, student engagement, and deepening thinking. The Residency I instructor provides feedback to the candidate on these indicators and how they performed during their lessons. The candidate works with the Residency I instructor to set goals for professional growth, specifically in planning, instruction, and assessment, and the specific indicators within those dimensions, such as improving questioning to deepen thinking or enhancing the use of visuals to improve student engagement.

A key assessment in TCHR 4991 is the diversity project. The candidate chooses an academic 
subgroup, within the context of his or her classroom, to study through a literature review. The first component of this assessment is the development of an annotated bibliography that highlights key research findings about the chosen academic subgroup. The second component is a plan to highlight key instructional strategies, supported by the literature review, that would be of benefit for the chosen subgroup. The candidate indicates in the lesson plan, that aligns with the video lesson, the strategies he or she incorporated that were supported by the literature review. This key assessment is to ensure connection of research to practice and understanding how to plan for varied student understanding.

\subsection{TCHR 4003, Classroom Management and Child/Adolescent Development}

The TCHR 4003 course is designed for candidates to examine evidence-based practices in effective classroom management, linked with theories and behavioral models. Candidates learn how to apply various classroom management techniques based on theories (Snowman \& McCown, 2012), such as the behaviorist model (Skinner \& Watson), assertive discipline (Canter), positive discipline (Jones), clear procedures (Wong), and choice theory (Glasser). Residency candidates reflect upon models that work best with their students' stage of development and with their style of teaching. They are expected to reflect upon how these self-chosen models work and where they need to improve, based upon their classroom teaching experience. A key assessment in the TCHR 4003 class is the development of a classroom management plan, grounded in theory, that addresses the unique needs of the candidate's students. This requires the candidate to develop a plan based on what he or she knows about the students using an assets-oriented approach to the learning environment that set the candidate and the students up for success.

\subsection{TCHR 4001, Curriculum, Instruction, and Assessment}

The TCHR 4001 course provides opportunities for candidates to learn about the state standards, applicable to the grade level they teach, but also expanding understanding across the continuum of the content to ensure knowledge of pre-requisite skills and how building content knowledge happens throughout the learning process. Candidates also learn about assessment strategies that teachers use, develop assessments that match learning objectives, and apply critical analysis of assessments created by others. The TCHR 4001 course facilitates a process for the candidate to analyze district- or school-mandated curricula and to determine the extent to which those materials align with, or not, the 6-step lesson plan process, and backward design. Residency candidates explore and design strategies that elicit student engagement and learn about effective questioning, especially questions that yield higher-order thinking.

The TCHR 4001 course also addressed student diverse needs from the candidate's vantage point. For example, a key assessment in the course was for the candidate to map the context for learning using the student profiles in his or her classroom. This map included the district and school context, community assets, and the cultural interests of the students with whom the candidate worked. The assessment facilitates the candidate's thinking about his or her students and how the knowledge of students is a key factor in lesson planning, instruction, and assessment. 


\subsection{Residency Supports}

While the coursework described was co-constructed with school district representatives, the workgroup believed it was important for the school district representatives to also be the instructors for TCHR 4991 and TCHR 4992. Residency instructors had an earned doctoral degree, current educator license, and demonstrated impact on student achievement in historically disadvantaged schools; the instructors were also practicing district employees. The TCHR 4991 and 4992 instructors served as an instructional coach to support the candidates in their experiences, while also understanding the scope of the coursework the candidates would take.

The residency instructors were provided with clinical educator training, edTPA training, and the use of video to provide feedback to novice teachers. The clinical educator training focused on how mentors identify evidence in the classroom, such as lesson plans, student behaviors, and teacher behaviors, to serve as coaching conversations for growth. The training included cultural competence, adult learning, and stages of teacher development.

The residency instructors used the GoReact platform to assess candidate delivery of a lesson. A 45-minute video of the candidate teaching his or her students was submitted into the platform, where the instructor provided time-stamped feedback aligned with the indicators associated with planning, instruction, and assessment. Candidates used this platform to watch their video and reflect on their performance using the same indicators the faculty used to provide feedback. The TCHR 4991 and 4992 instructors used this commentary to assess the growth in personal and professional reflection.

\section{Discussion}

\subsection{Lessons Learned}

The residency program provided opportunities for the ELMID department to examine its traditional coursework more closely. The workgroup recommended to the ELMID department that key assessments in existing courses be revised to reflect a more applicable bridge of theory to practice. For example, the diversity project assessed in TCHR 4991 was originally part of the Curriculum and Standards Course. In the traditional program, teacher candidates would choose a diversity interest, study it in the literature, and provide a reflection paper on strategies that could address the diversity group. Since TCHR 4991 provided that opportunity for candidates to choose a subgroup in a real class where he or she worked and to plan for how it would be addressed through lesson plans developed and taught, there was a need to shift that assessment in the traditional program. The Learning Theory and Instruction course is a place where that could occur, since traditional students complete a practicum experience, develop and deliver three lessons, and receive feedback from the university instructor.

Another lesson learned from the residency program development is that peer review of lessons is not only valuable to the candidate to receive feedback from a peer, but valuable to the peer providing the feedback. It was noted in evaluating candidates' peer feedback that growth in learning through application was evident. This yielded a higher commitment to reflecting upon video evidence, aligned with critical dimensions of teaching, and synthesizing 
to make meaning of the associated rubric constructs. This was also implemented in the Curriculum and Standards course, one of the first courses taken by candidates in the traditional pathway. While the video lesson is not a part of the course, reviewing a peer's lesson plan helped candidates in the traditional pathway develop a deeper understanding of the 6-step lesson plan process.

Finally, the residency program provided ELMID faculty with enhanced understanding of non-traditional students' needs. Candidates in the residency program are working professionals learning how to teach while also completing college coursework in an online environment. Faculty accessibility and immediate, just-in-time feedback is necessary to help residency candidates understand what they need to improve their practice. This requires faculty to think beyond the scope of office hours, adjusting their availability to meet the realistic needs of students. ELMID faculty understand that residency candidates, in particular, must be offered flexibility without compromising rigor. This means that, in residency, focusing on high-leverage teaching skills, coupled with real-time mentoring, is crucial for meaningful understanding of pedagogy and how it applies in real-world settings. School district feedback indicated preparedness to teach, and candidate feedback pointed to increased self-efficacy.

\subsection{Future Work}

There is a need to study the effectiveness of this one-year residency model using empirical measures. Because edTPA scores were not available at the time of this report, a follow-up study is needed. Short-term outcomes could be studied to determine the extent to which candidates successfully complete edTPA, the extent to which candidates yield satisfactory ratings on their teacher evaluations, and the extent to which candidates yield growth in student achievement. Long-term outcomes could be studied to determine the retention rates of the residency candidates, aligned with research on greater self-efficacy and teacher satisfaction. Faculty engagement in data examination from the program is critical for program change (McDiarmid, 2019). Therefore, there is a need for program faculty to closely examine longitudinal data to study the extent to which the residency program has impact on teacher retention, effectiveness, and impact on student achievement, in their respective school or district settings.

\subsection{Conclusion}

The residency program is one of several pathways to licensure. While colleges of education are often criticized for too much theory and not enough practice, this residency program proves potential in designing teacher preparation around meaningful experiences that connect theory and practice. This program development also ensured alignment of coursework with district needs to meet the unique needs of a diverse workforce. Course work and application in practice were supplemented by coaching and mentoring that addressed each candidate's unique needs. Providing alternative pathways, especially in historically disadvantaged communities with high turnover, is an effort to strengthen the educator pipeline in non-traditional ways. 


\section{References}

Alton, L. (2017). How millennials are reshaping what's important in corporate culture. Forbes. Retrieved from http://www.forbes.com

Barth, P., Dillon, N., Hull, J., \& Higgins, B. H. (2016). Fixing the holes in the teacher pipeline: An overview of teacher shortages. Center for Public Education. Retrieved from https://usba.cc/wp-content/uploads/2016/04/8d-Barth-CPE-Teacher-Shortage-Study_Web.pdf

Bastian, K. C., \& Marks, J. T. (2017). Connecting teacher preparation to teacher induction. American Educational Research Journal, 54(2), 360-394. https://doi.org/10.3102/000283 1217690517

Bastian, K. C., Lys, D., \& Pan, Y. (2018). A framework for improvement: Analyzing performance-assessment scores for evidence-based teacher preparation program reforms. Journal of Teacher Education, 69(5), 448-462. https://doi.org/10.1177/0022487118755700

Batchelor, K. (2012). Pre-service teacher education methods courses: From discipline to democracy. The Clearing House: A Journal of Educational Strategies, Issues and Ideas, 85(6), 243-247. https://doi.org/10.1080/00098655.2012.698324

Bohan, C. H. (2016). The past, present, and future of teaching and teacher education curriculum. Curriculum and Teaching Dialogue, 18(1), 3-12, 191. Retrieved from https://www.questia.com/library/journal/1G1-466413378/the-past-present-and-future-of-teach ing-and-teacher

Brinthaupt, T. M., \& Eady, E. (2014). Faculty members' attitudes, perceptions, and behaviors toward their nontraditional students. The Journal of Continuing Higher Education, 62(3), 131-140. https://doi.org/10.1080/07377363.2014.956027

Burn, K., \& Mutton, T. (2015). A review of 'research-informed clinical practice' in initial teacher education. Oxford Review of Education, 41(2), 217-233. https://doi.org/10.1080/ 03054985.2015.1020104

Chen, R., Daniels, E., \& Ochanji, M. (2017). Clinical practice in the center: Enhancing learning and collaboration in clinical practice through professional development learning community workshops. Middle School Journal, 48(4), 3-12. https://doi.org/10.1080/ 00940771.2017 .1343055

Council for the Accreditation of Educator Preparation. (2020). CAEP Standards. Retrieved from http://caepnet.org/standards/introduction

Darling-Hammond, L., \& Oakes, J. (2019). Preparing teachers for deeper learning. Harvard Education Press.

Davies, L., Dickson, B., Rickards, F., Dinham, S., Conroy, J., \& Davis, R. (2015). Teaching as a clinical profession: Translational practices in initial teacher education-an international perspective. Journal of Education for Teaching, 41(5), 514-528. https://doi.org/10.1080/ 02607476.2015.1105537 


\section{Macrothink}

Journal of Educational Issues

ISSN 2377-2263

2021, Vol. 7, No. 1

Dee, A. D. (2012). Collaborative clinical practice: An alternate field experience. Issues in Teacher Education, 21(1). 147-163. Retrieved from https://www.itejournal.org/ojs/index.php/ ite/article/view/42

Dennis, D. V. (2016). A teacher residency melds classroom theory with clinical practice. The Phi Delta Kappan, 97(7), 14-18. https://doi.org/10.1177/0031721716641642

Garcia, A., \& Garza, R. (2019). Chicago's bilingual teacher residency: A partnership to strengthen the teacher pipeline. Retrieved from https://files.eric.ed.gov/fulltext/ED599 744.pdf

Goodwin, A. L., Roegman, R., \& Reagan, E. M. (2018). Lessons from a teacher residency. Educational Leadership, 75(8), 62-68. Retrieved from http:/www.ascd.org/publications/ educational-leadership/may18/vol75/num08/Lessons-from-a-Teacher-Residency.aspx

Guha, R., Hyler, M. E., \& Darling-Hammond, L. (2017). The teacher residency: A practical path to recruitment and retention. The Education Digest, 83(2), 38-45. Retrieved from https://eric.ed.gov/?id=EJ1137804

Hargreaves, A., \& Fullan, M. (2012). Professional capital: Transforming teaching in every school. Teachers College Press.

Henry, G. T., Purtell, K. M., Bastian, K. C., Fortner, C. K., Thompson, C. L., Campbell, S. L., \& Patterson, K. M. (2014). The effects of teacher entry portals on student achievement. Journal of Teacher Education, 65(1), 7-23. https://doi.org/10.1177/0022487113503871

Indiana University School of Education. (2017). The Carnegie Classification of Institutions. Retrieved from http://carnegieclassifications.iu.edu/lookup/standard.php\#standard_basic 2005_list

Ingersoll, R., \& Merrill, L. (2010). Who's teaching our children? Educational Leadership, 67(8), 14. Retrieved from http://www.ascd.org/publications/educational-leadership/may10/ vol67/num08/Who\%27s-Teaching-Our-Childrenф.aspx

Kenner, C., \& Weinerman, J. (2011). Adult learning theory: Applications to non-traditional college students. Journal of College Reading and Learning, 41(2), 87-96. https://doi.org/ 10.1080/10790195.2011.10850344

Kurts, S. A., Cooper, J. E., \& Boyles, C. (2007). Project RESTART: Preparing nontraditional adult teacher education candidates to become special education teachers. Teacher Education and Special Education, 30(4), 233-236. https://doi.org/10.1177/088840640703000403

McDiarmid, G. W. (2019). Competing theories for improving teacher preparation programs: The case of North Carolina. ECNU Review of Education, 2(2), 117-136. https://doi.org/ $10.1177 / 2096531119853662$

National Center for Teacher Residencies. (2020). The Residency Model. Retrieved from https://nctresidencies.org/about/residency-model-teacher-mentor-programs

National Council for the Accreditation of Teacher Education. (2010). Transforming teacher 
education through clinical practice: A national strategy to prepare effective teachers. Retrieved from http://caepnet.org/ /media/Files/caep/accreditation-resources/blue-ribbonpanel.pdf

National Council on Teacher Quality. (2018). Best practices guide. Retrieved from https://www.nctq.org/publications/2018-State-Teacher-Policy-Best-Practices-Guide

North Carolina Department of Public Instruction. (2018). 2018-2019 state of the teaching profession in North Carolina. Retrieved from https://files.nc.gov/dpi/state-of-teachingprofession_20200310.pdf

North Carolina Department of Public Instruction. (2020a). 2019-2020 Low-performing schools, low-performing districts, recurring low-performing schools and continually low-performing charter schools. Retrieved from https://www.dpi.nc.gov/documents/2019\% E2\%80\%932020-low-performing-schools-low-performing-districts-recurring-low-performing -schools-and-continually-low-performing-charter-schools

North Carolina Department of Public Instruction. (2020b). Residency licensure. Retrieved from https://www.dpi.nc.gov/educators/educators-licensure/residency-licensure

North Carolina General Assembly. (2017). Senate Bill 599. Retrieved from https://www.ncleg. gov/Sessions/2017/Bills/Senate/PDF/S599v7.pdf

Pearson Education. (n.d.). edTPA. Retrieved from https://www.edtpa.com

Pike, L., \& Carli, M. (2020). Leveraging best practice in teacher residency to enhance teacher preparation. SRATE Journal, 29(2), 1-12. Retrieved from https://eric.ed.gov/?id=EJ1268558

Pritchard, K. (2017). First-year teachers' perceptions of their readiness for the classroom (Publication No. 2023840389, Doctoral dissertation, Gardner-Webb University). ProQuest Dissertations and Theses Global.

Ronfeldt, M., Loeb, S., \& Wyckoff, J. (2013). How teacher turnover harms student achievement. American Educational Research Journal, 50(1), 4-36. https://doi.org/10.3102/ 0002831212463813

Sass, T., (2015). Licensure and worker quality: A comparison of alternative routes to teaching. Journal of Law and Economics, 58(1), 1-35. https://doi.org/10.2139/ssrn.2283151

Snowman, J., McCown, R., \& Biehler, R. (2012). Psychology applied to teaching (13th ed.). Wadsworth Cengage Learning.

Stanford Center for Assessment, Learning, and Equity. (2016). edTPA user guide. Retrieved from https://www.edtpa.com/PageView.aspx?f=GEN_GettingStarted.html

Stanford Center for Assessment, Learning, and Equity. (2017). Making good choices: A support guide for edTPA candidates. Retrieved from https://www.edtpa.com/Content/Docs/ edTPAMGC.pdf

Sutcher, L., Darling-Hammond, L., \& Carver-Thomas, D. (2016). A coming crisis in teaching? 


\section{Macrothink}

Teacher supply, demand, and shortages in the U.S. Retrieved from https://learningpolicy institute.org/product/coming-crisis-teaching

Thorpe, R. (2014). Residency: Can it transform teaching the way it did medicine? Phi Delta Kappan, 96(1), 36-40. https://doi.org/10.1177/0031721714547860

United States Department of Education, National Teacher Preparation Data. (2017). 2017 Title II Report. Retrieved from https://title2.ed.gov/Public/Report/FullReport/FullReport. aspx? $\mathrm{p}=3 \_01$

University of North Carolina System. (2019). UNC educator quality research initiative. Retrieved from https://myapps.northcarolina.edu/p12division/educator-quality-data-and-resea rch-2

Washburn-Moses, L. (2017). A national descriptive survey of teacher residency programs. School-University Partnerships, 10(2), 33-41. Retrieved from https://eric.ed.gov/?id=EJ11 69298

Whitford, D. K., Zhang, D., \& Katsiyannis, A. (2018). Traditional vs. alternative teacher preparation programs: A meta-analysis. Journal of Child and Family Studies, 27(3), 671-685. https://doi.org/10.1007/s10826-017-0932-0

Wiggins, G., \& McTighe, J. (2012). Seven keys to effective feedback. Educational Leadership, 70(1), 10-16. Retrieved from http://www.ascd.org/publications/educational-lead ership/sept12/vol70/num01/Seven-Keys-to-Effective-Feedback.aspx

Winner, D. C., \& Paxton, A. Z. (2016). Increasing access to higher education through open and distance learning: Empirical findings from Mzuzu University, Malawi. International Review of Research in Open and Distance Learning, 17(4). https://doi.org/10.19173/irrodl. v17i4.2409

Zhang, G., \& Zeller, N. (2016). A longitudinal investigation of the relationship between teacher preparation and teacher retention. Teacher Education Quarterly, 43(2), 73. Retrieved from https://eric.ed.gov/?id=EJ1100322

\section{Copyright Disclaimer}

Copyright for this article is retained by the author(s), with first publication rights granted to the journal.

This is an open-access article distributed under the terms and conditions of the Creative Commons Attribution license (http://creativecommons.org/licenses/by/3.0/). 